\title{
The Ploutonion in the Archaeological Site of Hierapolis (Turkey): A Gate to the Underworld and the Knowledge
}

\author{
Cantisani $\mathrm{E}^{1}$, Vettori $\mathrm{S}^{1 *}$, Bracci $\mathrm{S}^{1}$, Degano $\mathrm{I}^{2}$, Lucejko J.J. ${ }^{2}$, Ismaelli $\mathrm{T}^{3}$ and D’Andria $\mathrm{F}^{4}$ \\ ${ }^{1}$ National Research Council-Institute for the Conservation and Valorization of Cultural Heritage, Sesto Fiorentino, Florence, Italy \\ ${ }^{2}$ Department of Chemistry and Industrial Chemistry, University of Pisa, Italy \\ ${ }_{3}^{3}$ Institute for Archaeological and Monumental Heritage (IBAM), National Research Council, Lecce, Italy \\ ${ }^{4}$ Department of Cultural Heritage, University of Salento, Italy
}

*Corresponding author: Silvia Vettori, National Research Council-Institute for the Conservation and Valorization of Cultural Heritage, Italy.

\author{
Received Date: May 31, 2019
}

Published Date: June 24, 2019

\begin{abstract}
The archaeological site of Hierapolis (Denizli, Turkey), one of the great Hellenistic, Roman and Byzantine cities of southwestern Turkey, protected by UNESCO since 1988, was built in the third century B.C. Even if damaged several times by earthquakes, it has survived for millennia. During antiquity, Hierapolis was a famous pilgrimage destination, the centre of a cult, because of the Ploutonion, the sanctuary dedicated to HadesPluto and his wife Kore-Persephone, visited also by Cicero and Strabo. In this paper the authors report the results obtained on some materials found in recent excavations carried out in the Ploutonion area. In particular, the investigated materials were a marble bust, a fragment of marble slab with painted scales and a piece of resin. Non-invasive (i.e. imaging techniques and portable X-Ray Fluorescence) and micro-destructive (i.e. X-Ray Diffraction, Fourier Transform Infrared spectroscopy, High-Performance Liquid Chromatography coupled to a Mass Spectrometry detector and Pyrolysis coupled with Gas Chromatography/Mass Spectrometry) have been employed to characterize the archaeological finds.
\end{abstract}

Keywords: Hierapolis archaeological site; Ploutonion; Madder lake; Egyptian blue; Pitch; Huntite

\section{Introduction}

Hierapolis of Phrygia was one of the main Hellenistic, Roman and Byzantine cities in South-Western in Asia Minor (Pamukkale, Denizli province, Turkey), protected by UNESCO since 1988, was built in the third century B.C. and, even if damaged several times by earthquakes, it has survived for over a millennium.

The site is also known for the white travertine waterfalls made of calcareous deposits of thermal waters which gave the name to the site ("Pamukkale" means "cotton castle") [1-3]. During the antiquity, Hierapolis was also a famous pilgrimage centre because of the presence of the Ploutonion, the sanctuary dedicated to Hades-Pluto and his wife Kore-Persephone, visited by numerous ancient writers, such as Cicero and Strabo [4]. The sanctuary was monumentalized during the early Imperial period (1st century B.C. - 1st century A.D.) exactly above the entrance to a natural cave, from which thermal waters and poisonous gases emerge. It was used for sacred rituals: sacrifices, incubation, healing. As referred by Strabo (XII, 4, 14), the Ploutonion grotto is characterized by the emission of gases, which were toxic to the animals approaching it during sacred rituals, while the Galli, the eunuch priests of the goddess Cybele, miraculously entered the cave and remained inside without any harm, demonstrating their supernatural power [4-6]. The gas composition is mainly characterized by $\mathrm{CO}_{2}$, that is colorless, odorless, and tasteless [7-8]. During the last years, the excavation conducted by the Italian Archaeological Mission, brought to light the entire sanctuary, discovering the grotto and the theatre, and numerous findings [4-5]. The internal walls of the natural cave were found entirely blackened and covered by manganese-based encrustations [9]. In this study, the characterization of different materials found in the excavation area of the Ploutonion is reported. 


\section{Materials and Methods}

\section{Materials characterization and archaeological context of discovery}

The materials investigated are shown in (Figure 1) and they are a marble bust, a marble slab with painted scales and a piece of resin. The marble bust without head (height $26 \mathrm{~cm}$; width $2 \mathrm{~cm}$; thickness $12 \mathrm{~cm}$ - Fig. 1a), was brought to light in the northern area of the Ploutonion: the bust was reused as a construction element in a wall (Stratigraphic Unit 247) dated to the early Byzantine period according to the construction technique and its stratigraphic position. A bust, with a quadrangular pedestal, is roughly worked with a toothed chisel on the bottom, rear and lateral faces. The male figure wears a chiton, while the shoulders are covered by a himation, with wide and flattened folds. The workmanship is rather rough. On the neck a metal pin $(2 \mathrm{~cm} \times 3 \mathrm{~cm})$ is inserted for fixing the head. In particular, the characterization of the bonding mortar coating the small metal pin was performed.
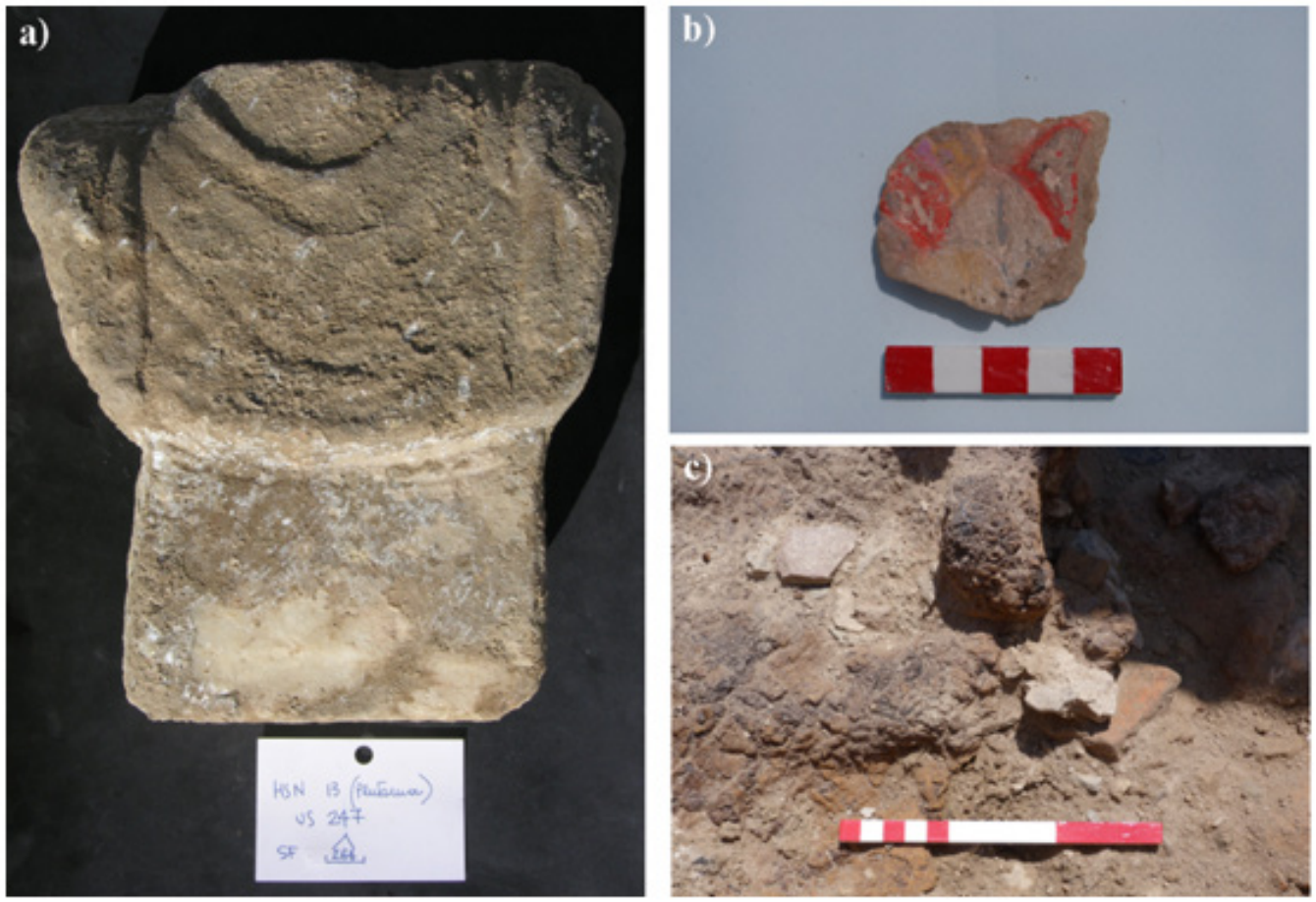

Figure 1: A) Marble bust; B) Marble slab with painted scales; C) Piece of resin.

The fragment of marble slab $(6 \times 4.6 \mathrm{~cm}$; thickness $1.2 \mathrm{~cm})$ (Figure 1b) was found in an area east of the sacred precinct. The slab has been discovered in a layer of dark and compact soil, rich in carbon residues that can be attributable to the discharge of the residues of the ritual activities practiced inside the sanctuary. On the front side, an imbricate pattern is present, with scales crossed by a longitudinal groove and painted in white, red, yellow and purple. The surfaces are slightly deteriorated. The piece of resin was discovered inside a rectangular deposit (SU 632) built against the south wall of the sacred precinct ( $3.2 \times 1 \mathrm{~m}, 1.5 \mathrm{~m}$ deep) (Figure 1c). The deposit, made of blocks of various sizes joined with mortar, was located below the floor level of a room, which was built in the early-Byzantine period (5th-6th century AD), when domestic structures were installed in the southern part of the sanctuary. The resin was conserved together with a pot, a basin and an amphora dated to the $6^{\text {th }}-7^{\text {th }}$ century AD [10].

\section{Analytical methodologies}

Among the non-invasive analytical methodologies, the imaging techniques were applied directly in situ for a first identification of the materials, as it was for other findings in the archaeological site of Hierapolis [11-12]. Direct acquisition of Ultraviolet fluorescence images (UVf), in order to identify fluorescent materials (i.e. organic remains such as wax, oil or red lakes) and Visible Induced Luminescence (VIL), able to detect any possible trace of Egyptian blue even if only some small particles were preserved on the surface, were performed [13-17]. For the photographic UVf, a digital camera Canon EOS 7D (18 Mpixel, CMOS sensor) was used. The camera was equipped with Canon lens EFS 28mm f/3.5-5.6 IS with $\mathrm{B}+\mathrm{W} 486 \mathrm{UV} / \mathrm{IR}$ blocking filter to cut both ultraviolet reflected and the possible infrared radiation stray generated by the lamps. As sources two Flash Quantum T5D with B+W UV black 403 filter were used. The same set-up was used for the visible images, the only difference being the removal of filter from the flashes. For VIL acquisitions, the finds were irradiated with visible light by using two flashes Quantum T5D mounted with B+W 486 UV/IR filters; the infrared emission was collected with a modified (built-in filter for IR removed) Canon EOS 400D (10.1 Mpixel, CMOS sensor) with Canon lens EFS 28mm fitted with B+W 093 blocking filter to cut all stray radiation from visible spectrum and thus collecting only infrared luminescence emission. A white plate Spectralon $\AA$ was used as reference. In laboratory, the visible light and UV 
images of the materials and/or sampled portions were acquired by a Nikon Eclipse E600 optical microscope. X-Ray Fluorescence (XRF) spectra were collected by means of handheld Tracer III SD Bruker spectrometer, equipped with rhodium anode. For every measurement, the working energy used was $40 \mathrm{kV}-12 \mu \mathrm{A}$. The spectrometer detector is a SDD (FWHM $<145 \mathrm{eV}$ at $100.000 \mathrm{cps}$ ). The instrument with this configuration can collect X-ray emission from Sulphur ( $\mathrm{K}$ line) to lead ( $\mathrm{L}$ lines). Usually, the presence of elements with high atomic number, conceals the signals of lighter elements and, in this case, it is possible to identify only elements starting from calcium (K lines).

Microsamples were collected for laboratory analyses such as X-ray diffraction (XRD) and Fourier transform infrared spectroscopy (FT-IR). Powdered samples were analysed with a PANalytical diffractometer X'Pert PRO with radiation $\mathrm{CuK} \alpha 1=$ $1.54 \mathrm{~A}$, operating at $40 \mathrm{kV}, 30 \mathrm{~mA}$, investigated range $2 \theta 3^{\circ}-70^{\circ}$, equipped with $X^{\prime}$ Celerator multidetector. High score data acquisition and interpretation software for determining the mineralogical composition were used. FT-IR spectra of the resin were collected with a portable Bruker Optics ALPHA FT-IR Spectrometer equipped with SiC Globar source and a DTGS detector. All spectra were acquired in transmittance mode on micro-samples embedded in $\mathrm{KBr}$ pellets with a resolution of $4 \mathrm{~cm}^{-1}$ in the $4000-400 \mathrm{~cm}^{-1}$ range and 16 scans. The collected IR spectra were processed using OPUS 7.2 software.

The resin was analysed by Py-GC/MS in the presence of a derivatization agent (HMDS). Analytical pyrolysis was performed using $3 \mu \mathrm{L}$ of 1,1,1,3,3,3-hexamethyldisilazane (HMDS, chemical purity 99.9\%, Sigma Aldrich Inc., USA) as a silylation agent for the in situ thermally assisted derivatization of pyrolysis products. The instrumentation consisted of EGA/PY-3030D Multi-Shot micro-furnace pyrolyser (Frontier Lab, Japan) coupled with a gas chromatograph (6890 Agilent, USA) equipped with an HP-5MS fused silica capillary column (stationary phase 5\% diphenyl e 95\% dimethyl-polysiloxane, 30 m x 0.25 mm i.d., Hewlett Packard, USA) and with a deactivated silica pre-column ( $2 \mathrm{~m} \times 0.32 \mathrm{~mm}$ i.d., Agilent J\&W, USA). The GC was coupled with an Agilent 5973 Mass Selective Detector operating in electron impact mode (EI) at $70 \mathrm{eV}$. The pyrolysis temperature was $550^{\circ} \mathrm{C}$ and was carried out for $20 \mathrm{~s}$. Chromatographic conditions: initial temperature $60^{\circ} \mathrm{C}, 2$ min isothermal, $15^{\circ} \mathrm{C} \mathrm{min}^{-1}$ to $100^{\circ} \mathrm{C}, 3 \mathrm{~min}$ isothermal, $4^{\circ} \mathrm{C} \mathrm{min}{ }^{-1}$ to $200^{\circ} \mathrm{C}, 5 \mathrm{~min}$ isothermal, $15^{\circ} \mathrm{C} \mathrm{m^{-1 }}$ to $280^{\circ} \mathrm{C}, 5 \mathrm{~min}$ isothermal. Carrier gas: He (purity 99.995\%), constant flow $1.0 \mathrm{ml} \mathrm{min}^{-1}$. A purple pigment belonging to marble fragment (Figure 1b) was analysed by high performance liquid chromatography (HPLC). The coloring material was extracted from the sample by applying a methanolysis treatment. It consists in the following steps: addition of $300 \mu \mathrm{L}$ of $\mathrm{MeOH} / \mathrm{HCl}$ (30:1) solution; extraction in ultrasonic bath at $60^{\circ} \mathrm{C}$ for 60 minutes; filtration with PTFE $(0.45 \mu \mathrm{m})$ filters; evaporation under nitrogen flow; re-dissolution with $100 \mu \mathrm{L}$ of DMSO; injection of $20 \mu \mathrm{L}$ of the extract in HPLC-DAD and $10 \mu \mathrm{L}$ in the HPLC-ESI-Q-ToF respectively. More details on the instrumental conditions and parameters are reported in the literature [18-19].

\section{Results and Discussion}

\section{Marble slab with painted scales}

The observations by VIL imaging technique, performed in situ, allowed us to identify the blue pigment as Egyptian blue. VIL image in Figure $2 \mathrm{~b}$ shows intense luminescence (i.e. light areas indicate the presence of Egyptian blue). Moreover, Egyptian Blue seems to be present also in correspondence to the purple area (Figure 2). In this area, the UVf image (Figure 2c) highlights a pinkish fluorescence, which suggests the presence of a red lake. So, probably, a red lake mixed with Egyptian blue was used in order to obtain a purple tone.

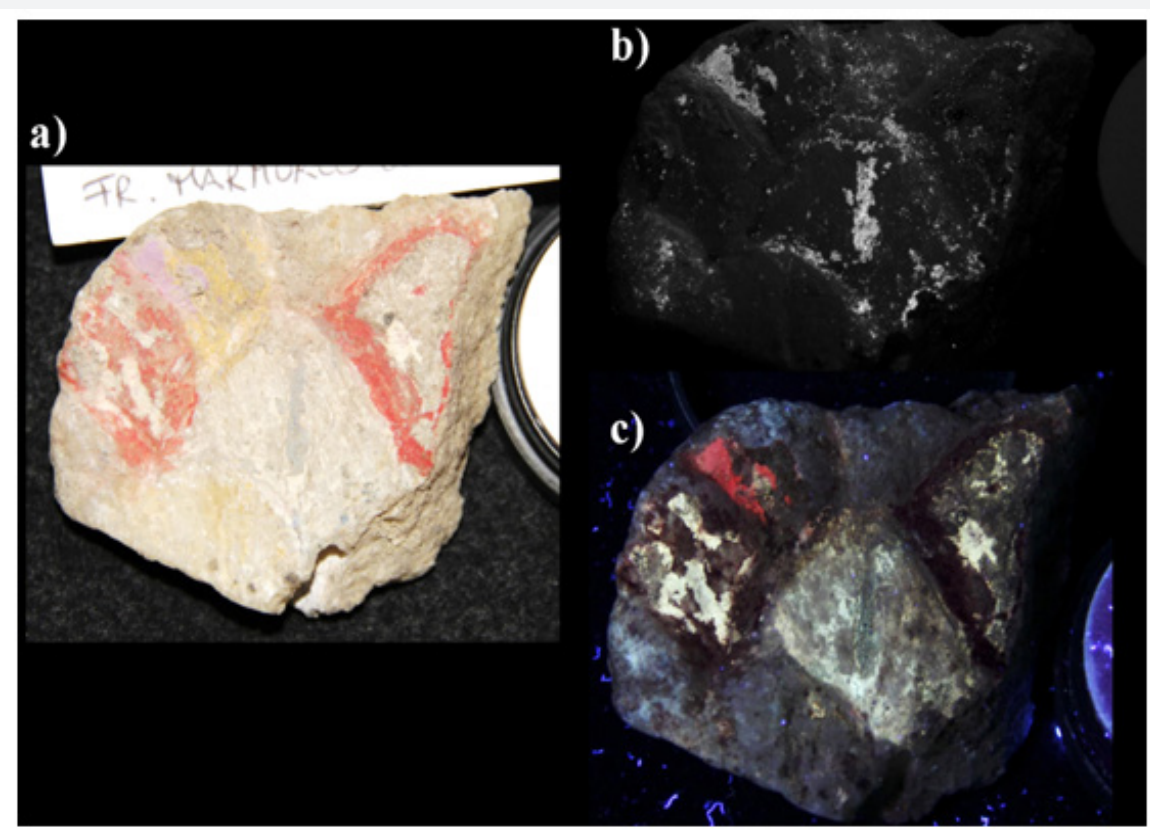

Figure 2: a) Visible, b) VIL and c) UVf images of the marble slab painted with scales. 
Thanks to micro sampling and laboratory analyses (i.e. XRF and XRD), the use of yellow ochre (that owes its colour to iron oxides/ hydroxides), cinnabar ( $\mathrm{HgS})$ and calcium carbonate $\left(\mathrm{CaCO}_{3}\right)$, respectively for yellow, red and white pigments was confirmed. The XRD analyses also confirmed that the blue pigment is Egyptian Blue, a synthetic pigment in which the colour is given by cuprorivaite (calcium copper (II) silicate, $\mathrm{CaCuSi}_{4} \mathrm{O}_{10}$ ). The analysis by high performance liquid chromatography (HPLC) with UV-Vis Diode Array spectrophotometric detector (HPLC-DAD) of the extract did not allow to identify any significant peak in the chromatogram.
The analysis performed with HPLC interfaced through an Electro Spray Ion source with a high-resolution tandem mass spectrometer allowed us to detect alizarin in the sample, suggesting the occurrence of a madder-based lake. The chromatogram corresponding to the Extracted Ion Chromatogram of alizarin, its ESI mass spectrum (acquired in negative ionization mode) and tandem mass spectrum are reported in Figure 3. None of the anthraquinones possibly present as minor components in madder species was detected; thus, the positive identification of the raw material employed to produce the lake cannot be achieved [20-24].
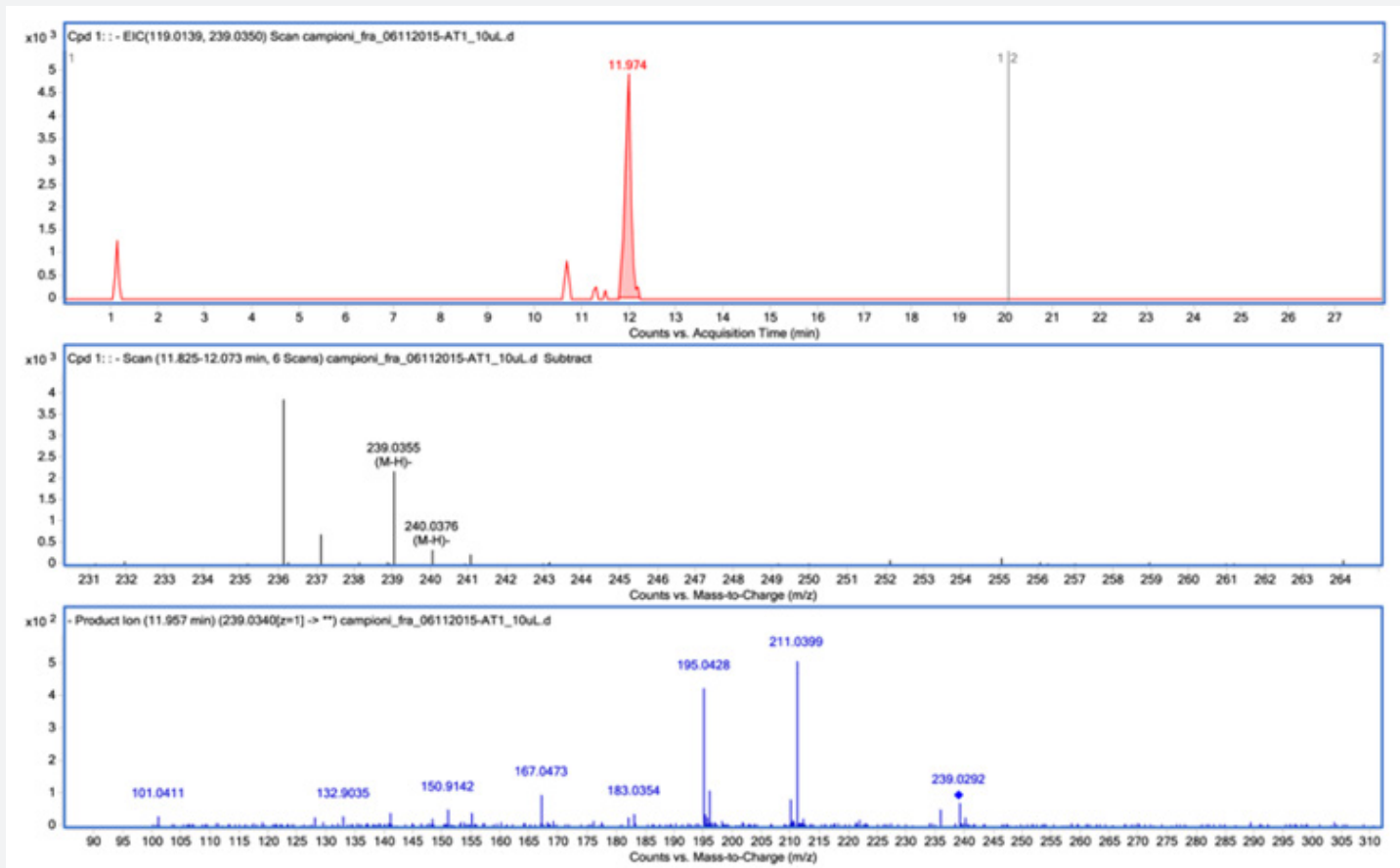

Figure 3: HPLC-ESI-Q-ToF extracted ion chromatogram of the sample, corresponding to the exact mass of alizarin (top); ESI- Mass spectrum of alizarin (middle); Tandem mass spectrum of the ion at $239.02 \mathrm{~m} / \mathrm{z}$ corresponding to alizarin [M-H]- ion (bottom).

A specific relationship between the detected madder lake and the territory was found. Numerous inscriptions and various historical accounts report that the city was particularly renowned for its textile production, which still today imprints the economic activities of the surrounding territory [25-26]. The hot springs and the bicarbonate-calcium rich composition of the thermal waters [7] were the origin of the success of the textile manufacture of Hierapolis, which flourished in Roman age, but that could have had a certain importance, at least at regional level, even before, in the pre imperial era. At the time of Augustus, Strabo (XIII, 4, 14) reports on the use of the roots of a plant (which could have been madder) from which an excellent purple-red tincture was obtained. Furthermore, Strabo relates that the thermal waters of Hierapolis were so suited for dyeing that the woollen yarns dyed with the roots of a plant could compete with those dyed elsewhere with cochineal, kermes or even Tyrian purple [27-28]. Interestingly, the composition of the analysed red lake, detected on the basis of the presence of alizarin only, is consistent with the use of Rubia as raw material, which grows spontaneously in the region and was probably exploited in the dyeing of textiles in antiquity.

\section{Piece of resin}

(Figure 4) shows the photographic documentation, both in visible light and in ultraviolet fluorescence, of a portion of the resin block. The intense fluorescence suggests the presence of organic compounds. The optical microscope image, related to the contact between the internal part and the surface of the material, highlights a certain level of continuity, suggesting that it might be the same material. In Figure 5 the chromatographic profile obtained by Py-GC/MS is reported. The analysis revealed the presence of diterpenoid species characteristic of pine resin as: isopimaric acid, dehydroabietic acid, didehydroabietic acid and 7-oxo-deidroabietc acid (respectively: \#4, \#6, \#7 and \#8). Products such as: 19-norabietatriene, tetra hydroretene, retene, methyl dehydroabietate (respectively \#1, \#2, \#3 and \#5) and a series of polycyclic aromatic hydrocarbons (PAH) indicate that the pine resin was thermally treated (heated in absence of oxygen). The presence of retene is considered as a molecular marker of pine pitch. Retene, as well as 19-norabietatriene and tetrahydroretene were formed while pine resin is heated at high temperature or distilled [29]. Methyldehydroabietate is produced when the heating of resin takes 
place in the presence of wood. For this reason, we can assume that the analysed material that contains pine pitch was obtained by heating the resin from the Pinacea family in presence of wood.
The FT-IR spectrum of the sample compared with reference spectra of the IRUG database (Infrared \& Raman Users Group) shows a spectral profile compatible with a pine pitch (Figure 6).

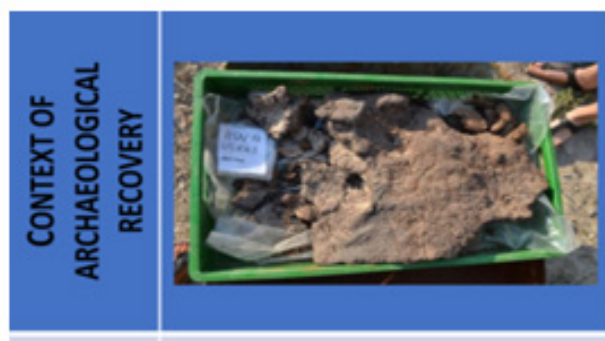

VISIBLE LIGHT
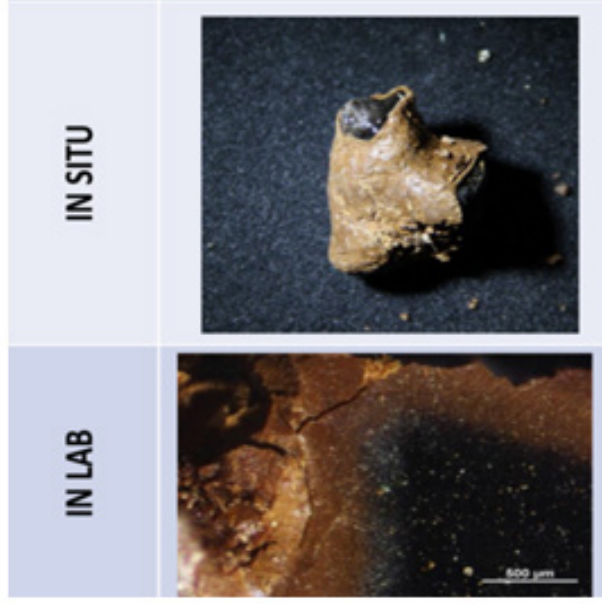

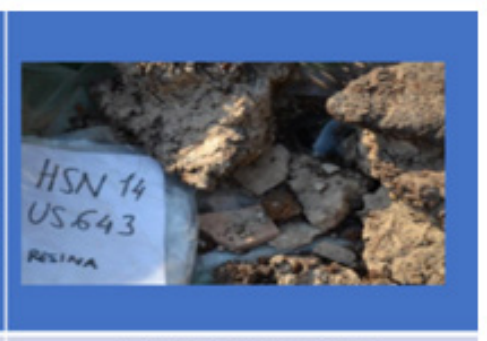

ULTRAVIOLET FLUORESCENCE
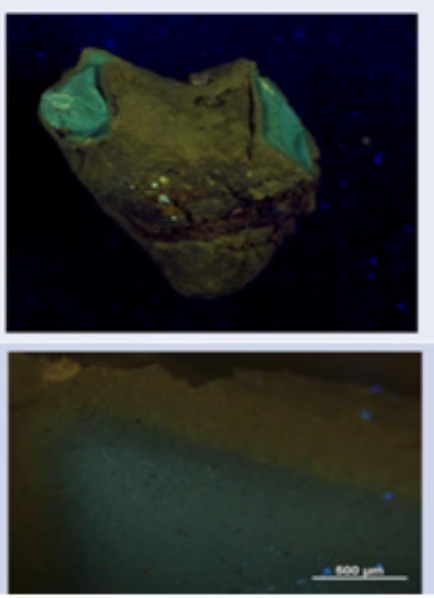

Figure 4: Visible and UVf images by optical microscopic of a portion of the piece of resin both in situ and in laboratory (under microscope). Also, the context of the archaeological discovery is reported.

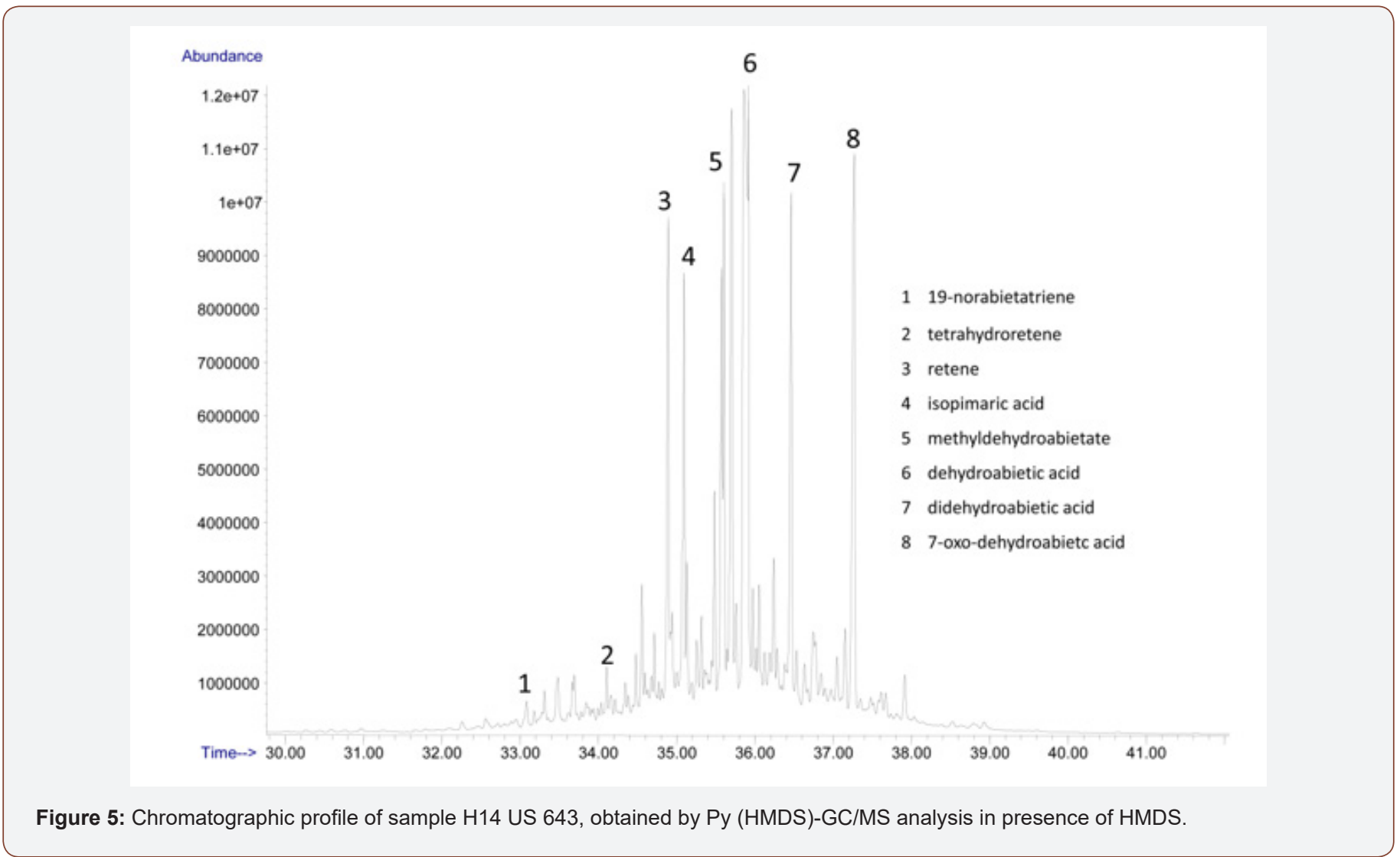




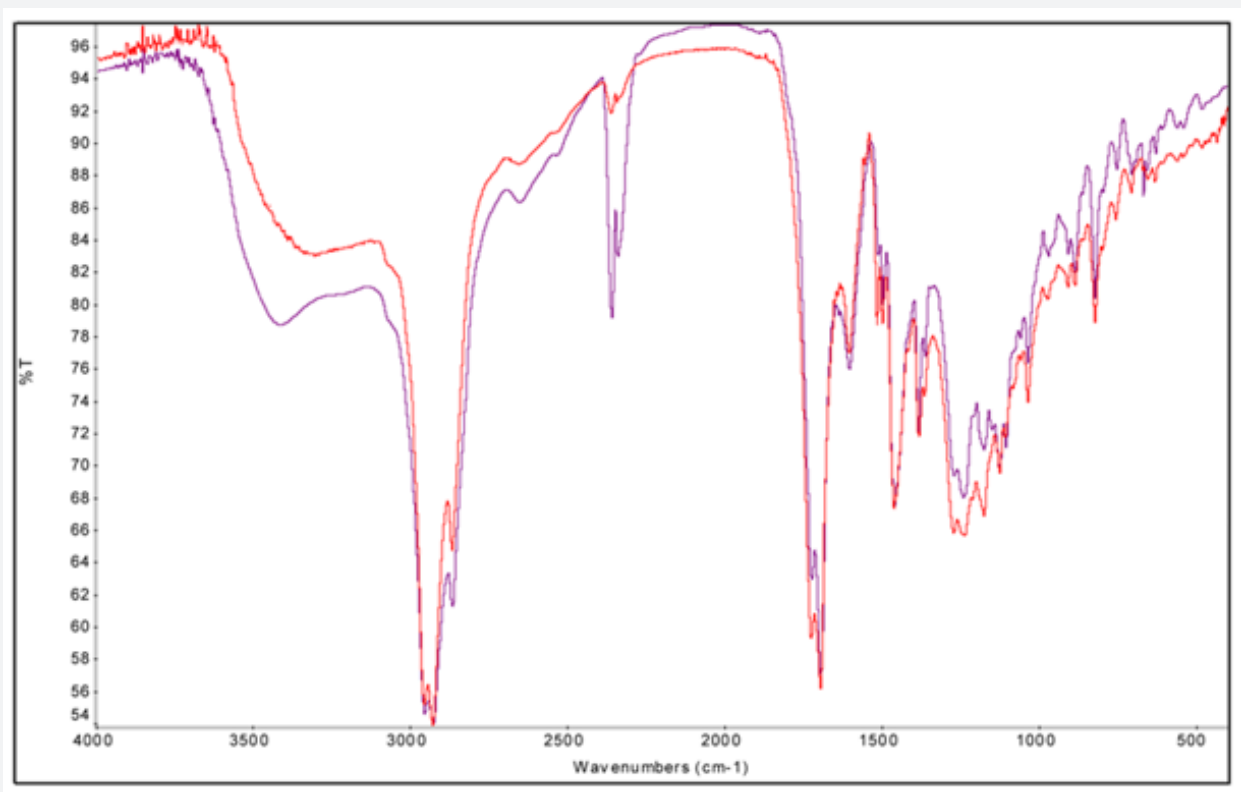

Figure 6: Infrared spectrum of the resin sample (in violet) in comparison with the reference spectrum of a pine pitch by IRUG (Infrared \& Raman Users Group) database (in red).

\section{Marble bust}
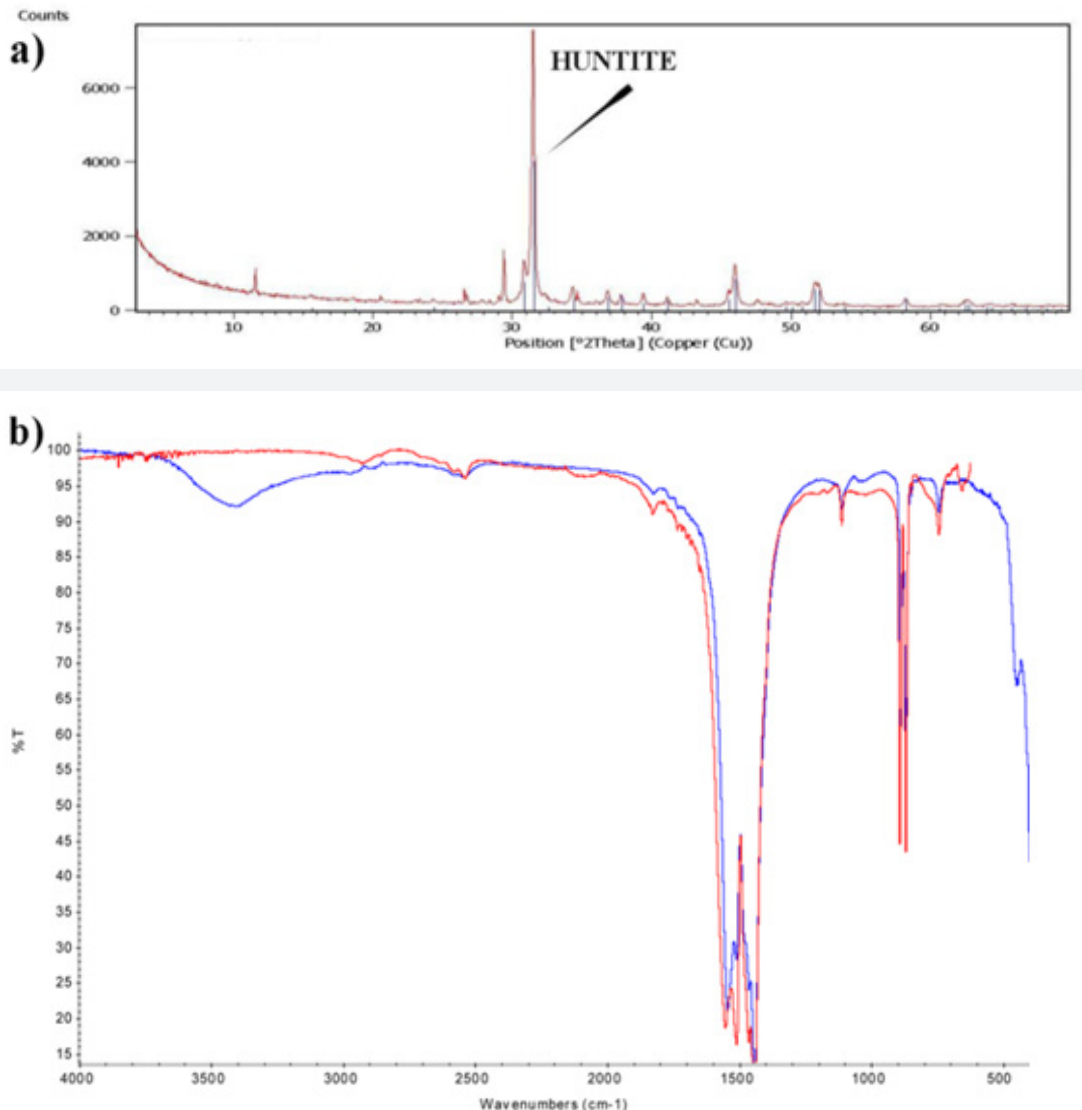

Figure 7: a) Diffraction pattern of the material that covered the metal pin; b) Infrared spectrum of the sample (in blue) in comparison with the reference spectrum of huntite ( $\mathrm{CaMg} 3(\mathrm{CO} 3) 4)$ by IRUG (Infrared \& Raman Users Group) database (in red).

The analyzed sample of the marble bust comes from the material that covered the metal pin $(2 \mathrm{~cm} \times 3 \mathrm{~cm})$ on the neck for fixing the head. The XRD analysis (Figure $7 \mathrm{a}$ ) revealed the presence of huntite $\left(\mathrm{CaMg}_{3}\left(\mathrm{CO}_{3}\right)_{4}\right)$, a magnesium calcium carbonate as the main mineralogical phase, calcite, quartz and gypsum in smaller amount. Moreover, the IR spectrum shows a characteristic spectral profile compatible with that of huntite in the IRUG database (Infrared \& Raman Users Group) (Figure 7b). No organic substance was found. 
Several studies have shown that huntite mineral was already used before Greek and Roman Periods. In a shipwreck dated back between $3^{\text {rd }}$ and $4^{\text {th }}$ century A.D. in the Procchio Gulf (Elba Island, Italy) $10 \mathrm{~kg}$ of huntite in a wooden box were discovered, suggesting the use either as pigment or as cosmetic [30]. The use of huntite as pigment on Ancient Egyptian artefacts at the Museum of Egyptian of Art in Munich was described by Riederer [31]. Heywood [32] showed that huntite was used for common objects in Egyptian art as well as for those produced for the royal family. Huntite continues to appear frequently through the Second Intermediate Period and in the New Kingdom up to the Third Intermediate Period. It was less used during the Late, Ptolemaic, and Roman Periods. In the specific case of the marble bust, the huntite was used as bonding mortar. This use is very interesting because huntite has specific physicomechanical characteristics, which make it suitable as fire retarding in the chemical factories today [33-34]. Nonetheless, accordingly to bibliographical sources, huntite is not present in the Denizli basin where Hierapolis is located. Today, the main extraction district lies in south west of Turkey, in Acıpayam about $60 \mathrm{Km}$ from Hierapolis. These huntite mines are located on the plateau crossed by the ancient main road between Hierapolis and the ancient coastal cities of Pamphylia (such as Attaleia, Perge, Aspendos, Side), from where the mineral may have been exported also in the Mediterranean basin.

\section{Final Remarks}

A multi-analytical approach was applied both in situ and in laboratory in order to discover raw materials and technologies used by ancient inhabitants of Hierapolis. Findings discovered during the excavation of the Ploutonion enlighten the recipes of pigments used for the decoration on marbles (madder lake, Egyptian blue, ochres, calcite and cinnabar), the knowledge of pitch resin as waterproofing materials and the use of huntite as bonding mortars. In such way the Ploutonion can be considered not only a gate for underworld but above all a source of knowledge.

\section{Acknowledgement}

This research was co-founded by MIUR in the framework of the Italian FIRB 2012 Project "Marmora Phrygiae".

\section{Conflict of Interest}

No conflict of interest.

\section{References}

1. Altunel E, Barka A (1996) Evaluation of archaeoseismic damages at Hierapolis. Geol Bull Turkey 39: 65-74.

2. Piccardi L (2007) The AD 60 Denizli Basin earthquake and the apparition of Archangel Michael at Colossae (Aegean Turkey). Geol Soc Lond Spec Publ 273(1): 95-105.

3. Kumsar H, Aydan Ö, Şimşek C, D’Andria F (2016) Historical earthquakes that damaged Hierapolis and Laodikeia antique cities and their implications for earthquake potential of Denizli basin in western Turkey. Bulletin of Engineering Geology and the Environment 75 (2): 519-536.

4. D’Andria F (2013) Il Ploutonion a Hierapolis di Frigia. Istanbuler Mitteilungen 63: 157-217.

5. D'Andria F, Ismaelli T, Panarelli P (2016) Initial data on the supply of marble for the Ploutonion. In: Ismaelli T, Scardozzi G (Eds.), Ancient Quarries and Building Sites in Asia Minor, Italy, pp: 365-372.
6. Bozza S (2016) The Ionic Portico of the Ploutonion in Hierapolis of Phrygia. In: Ismaelli T, Scardozzi G (Eds.), Ancient Quarries and Building Sites in Asia Minor, Italy, pp: 373-384.

7. Vettori S, Cabassi J, Cantisani E, Riminesi C (2019a) Environmental impact assessment on the stone decay in the archaeological site of Hierapolis (Denizli, Turkey). Sci Total Environ 650: 2962-2973.

8. Pfanz H, Yüce G, Gulbay AH, Gokgoz A (2018) Deadly CO2 gases in the Plutonium of Hierapolis (Denizli, Turkey). Archaeological and Anthropological Sciences

9. Vettori S, Cantisani E, Chelazzi L, Cuzman OA, Gatta GD, et al. (2019b) The dark colour of the Ploutonion at Hierapolis of Phrygiae (Turkey). Archaeometry 61(2): 296-308.

10. Panarelli P (2018) The Ploutonion of Hierapolis in Phrygia in the Late Ancient and Proto-Byzantine Period. In: Şimşek C, Kaçar T(Eds.), The Lykos Valley and Neighborhood in Late Antiquity, Laodikeia Çalişmalari Supplementary Series 1, Turkey, pp: 325-340.

11. Vettori S, Bracci S, Cantisani E, Conti C, Ricci M, et al. (2019c) Archaeometric and archaeological study of painted plaster from the Church of St. Philip in Hierapolis of Phrygia (Turkey). Journal of Archaeological Science: Reports 24: 869-878.

12. Bracci S, Vettori S, Cantisani E, Degano I, Galli M (2019) The ancient use of colouring on the marble statues of Hierapolis of Phrygia (Turkey): an integrated multi-analytical approach. Archaeological and Anthropological Sciences 11(4): 1611-1619.

13. Verri G, Clementi C, Comelli D, Cather S, Pique F (2008) Post-capture data analyses as an aid to the interpretation of ultraviolet-indiced fluorescence images. In: Stork DG, Coddington J (Eds.), Computer Image Analyses in the Study of Art, USA, pp: 681001-681012.

14. Warda J, Frey F, Heller D, Kusheld D, Vitale T, Weaver G (2012) Ultraviolet photography. In: Warda J (edt.) AIC guide to digital photography and conservation documentation, American Institute for Conservation of Historic and Artistic Works, USA.

15. Accorsi G, Verri G, Bolognesi M, Armaroli N, Clementi C, et al. (2009) The exceptional near-infrared luminescence properties of cuprorivaite (Egyptian blue). Chem Commun (23): 3392-3394.

16. Verri G (2009) The spatially resolved characterization of Egyptian blue, Han blue and Han purple by photo-induced luminescence digital imaging. Anal Bioanal Chem 394(4): 1011-1021.

17. Dyer J, Verri G, Cupitt J (2013) Multispectral Imaging in Reflectance and Photo-induced Luminescence modes: a user manual.

18. Lluveras Tenorio A, Parlanti F, Degano I, Lorenzetti G, Demosthenous D, et al. (2017) Spectroscopic and mass spectrometric approach to define the Cyprus Orthodox icon tradition - The first known occurrence of Indian lac in Greece/Europe. Microchemical Journal 131: 112-119.

19. Degano I, Łucejko JJ, Colombini MP (2011) The unprecedented identification of Safflower dyestuff in a 16th century tapestry through the application of a new reliable diagnostic procedure. Journal of Cultural Heritage 12(3): 295-299.

20. Cardon D (2003) Le monde des tenintures naturelles, France.

21. Hofenk de Graaff JH (2004) The Colourful Past: Origin, Chemistry and Identification of Natural Dyestuffs, Abegg-Stiftung and Archetype, London.

22. Degano I, Ribechini E, Modugno F, Colombini MP (2009) Analytical Methods for the Characterization of Organic Dyes in Artworks and in Historical Textiles. Appl Spectrosc Rev 44: 363-410.

23. Sabatini F, Lluveras Tenorio A, Degano I, Kuckova S, Krizova I, et al. (2016) A Matrix-Assisted Laser Desorption/Ionization Time-of-Flight Mass Spectrometry Method for the Identification of Anthraquinones: The Case of Historical Lakes. J Am Soc Mass Spectrom 27(11): 18241834.

24. Colombini MP, Degano I, Ribechini E (2017) A multi analytical approach to determine Madder lake in a funerary clay vessel found in a chamber tomb in Taranto. In: Kirby (Edt.), Divers Dye Hist Archaeol Archetype, England. 
25. Ritti T (1995) Associazione di mestiere a Hierapolis di Frigia. In: Giannattasio B (edt.) Viaggi e commerci nell antichità, Atti VII Giornata archeologica, Italy, pp: 65-84.

26. Ritti T (2017) Hierapolis di Frigia IX, Storia e istituzioni di Hierapolis. Ege Yayınları, Turkey.

27. Baumann H (1982) Die griechische Pflanzenwelt in Mythos, Kunst und Literatur, Germany.

28. Levick B (2004) The Roman economy. Trade in Asia Minor and the niche market 51: 180-198.

29. Colombini MP, Giachi G, Modugno F, Ribechini E (2005) Characterization of Organic Residues in Pottery Vessels of the Roman Age from Antinoe (Egypt). Microchemical Journal 79(1-2): 83-90.
30. Barbieri M, Calderoni G, Cortesi C, Fornaseri M (1974) Huntite, a mineral used in antiquity. Archaeometry 16(2): 211-220.

31. Riederer J (1974) Recently identified Egyptian pigments. Archaeometry 16: 102-109.

32. Heywood A (2001) The use of huntite as a white pigment in ancient Egypt. In: Davies WV (edt.) Colour and Painting in Ancient Egypt, British Museum Press, England, pp: 5-9.

33. Atay HY, Celik E (2010) Use of Turkish huntite/hydromagnesite mineral in plastic materials as a flame retardant. Polym Comp 31(10): 16921700.

34. Atay HY, Çelik E (2012) Electrical Behaviors of Flame Retardant Huntite and Hydromagnesite Reinforced Polymer Composites. Polym Sci, pp: $1-9$ 